\title{
The plight of absent fathers caused by migrant work: Its traumatic impact on adolescent male children in Zimbabwe
}

\author{
Authors: \\ Ananias K. Nyanjaya ${ }^{1}$ \\ Maake J. Masango ${ }^{1}$ \\ Affiliations: \\ ${ }^{1}$ Department of Practical \\ Theology, University of \\ Pretoria, South Africa \\ Note: \\ This article is an adaptation \\ of Ananias Nyanjaya's PhD \\ dissertation, undertaken \\ within the Department of \\ Practical Theology at the \\ University of Pretoria and \\ supervised by Prof. Maake \\ Masango. \\ Correspondence to: \\ Maake Masango \\ Email: \\ maake.masango@up.ac.za \\ Postal address: \\ PO Box 84173, Greenside \\ 2034, South Africa \\ Dates: \\ Received: 25 Nov. 2010 \\ Accepted: 16 Sept. 2011 \\ Published: 18 Apr. 2012 \\ How to cite this article: \\ Nyanjaya, A.K. \& Masango, \\ M.J., 2012, 'The plight of \\ absent fathers caused by \\ migrant work: Its traumatic \\ impact on adolescent male \\ children in Zimbabwe', \\ HTS Teologiese Studies/ \\ Theological Studies 68(1), \\ Art. \#1004, 10 pages. http:// \\ dx.doi.org/10.4102/hts. \\ v68i1.1004
}

C 2012. The Authors. Licensee: AOSIS OpenJournals. This work is licensed under the Creative Commons Attribution License.
This article revealed the degree of trauma experienced by male adolescents when their fathers are absent. The cost of this absence could not be balanced with the material benefits the children have enjoyed, for the benefits have been outweighed by the trauma that children experience in the absence of their fathers. The emotions and tears expressed during the research journey have revealed that material support cannot compensate for the love and presence children expect from their fathers. The deep hurt instilled in their hearts by the periods of absence angered them and led to traumatic experiences. The protracted period of living with only one primary caregiver has imprisoned them into the feminised environment, thereby robbing them of a male identity. Therefore, this article was devoted to creating a shepherding model of caring for boys whose fathers are absent.

\section{Introduction}

In Zimbabwe, African male children are raised into adulthood through the guidance of their fathers. The role of a father has been significant for many years and it is still central in the life of the boy child. However, the exodus of men to the Diaspora poses a serious challenge to the dearly held tradition of raising a boy child in Zimbabwe. As a narrative researcher, the primary author chose to write an article on the effects of absent fathers who have left to pursue migrant work and the traumatic impact of this on their adolescent male children in Zimbabwe. Narrative researchers are concerned with stories of marginalised people or with that which people give little attention. Before undertaking the research, the primary author had not realised that the boy children missed their fathers. He perceived these children as being better than those with resident fathers because he thought that they were being adequately provided for materially. In this study, a resident father is defined as a man who, in 2008, earned a monthly salary equating to billions of Zimbabwean Dollars, but yet was still unable to meet the daily financial needs of himself or his family because of the harsh economic conditions in prevalent in that country.

\section{Motivation for the article}

Growing up with his parents helped the primary author to form a gender identity drawn from their influence. In his journey into adulthood he learnt what it means to be a father and what a good wife is like from each of these very special people in his life. As an adult today, he still recognises his father's teaching and influence. The pains and joys that he experienced as he journeyed with his parents are part of his life today. In addition, as a minister of religion who has worked with young people for more than two decades, he sought to understand whether the absence of fathers is traumatic to male adolescents. The findings would help the primary author to understand some of the behaviours that adolescent boys exhibit in his care for them. Furthermore, it would help him to work with the adolescents to find a model that would be of benefit to those in such risky environments. The aim of this study is not to deal specifically with the detailed effects of the father's absence, but rather to determine whether this deficiency can be labelled as traumatic for those adolescent male children affected. This is because there are several factors that cause individuals to behave in the way they do in people's lives.

\section{Historical perspective on male migrant work}

In the past, men from Zimbabwe migrated to South Africa to be employed as mine workers, gardeners and cooks. These migrants left their families behind for many years before they returned to them, if they even returned at all. In this article, the authors aim to assess the effects that absent fathers have on adolescent boys when they migrate to other countries and continents in search of work, leaving their sons behind. Migration has forced many of these children to grow up without adult supervision, unlike in the past where men in their extended family took up the role 
of the absent fathers. Children today are therefore growing up without sufficient male role models, especially where mothers, maids and strangers are left to take care of them. In the past, the village was mandated by the elders to look after and discipline children, as opposed to the contemporary manner in which most children are reprimanded only by their parents.

This has played out on a global scale as well, whereby the courts, through child protection acts or related legal frameworks, outline how children should be cared for. Therefore, the raising of children has become a nightmarish situation for many parents because of the limitations imposed onto them by these legal frameworks. Parents now fear to control their children because this can be construed as child abuse, a fear which has caused anxiety to penetrate all facets of the community life that must nurture the child. This has made many caregivers and guardians in the urban setting to loosen or compromise their role. To this end, Gerkin (1997), drawing on the arguments of Lasch, states that:

Lasch was highly critical of the way in which the professionals in the field of childcare had invaded the homes of America, subtly undermining the authority of parents and setting themselves up as the 'experts' on family life. The result, said Lasch, was a host of American parents who did not trust their own judgments: a state that can easily lead to frustration resulting in violence. ( $p$. 233)

The challenges noted by Gerkin reflect what the Zimbabwean families are going through, which makes it difficult for family members to guide children in a traditional manner. The reader should note that, in Zimbabwe, there are some initiation ceremonies that were previously carried out for the boys' passage into adulthood. At present, these ceremonies are being conducted only sparingly in some cultures as the success of these ceremonies depends upon the integral involvement of adult men. Regrettably, the men who are supposed to explain and initiate these ceremonies for adolescents are not in attendance because they are working as migrant labourers elsewhere and are undermined by legal framework. In addition, children living in urban areas do not regularly visit their rural homes to be guided by male relatives, particularly when their father is absent.

\section{Statement of the problem}

Any researcher or layperson knows that an issue is generally studied or looked at seriously when a problem has arisen. Therefore questions are asked, such as: What is the problem? Why does the problem arise? What are the conditions in which the problem arises? In this study, the questions asked were: How can an adolescent male child develop a male identity in the absence of their father in Zimbabwe? Are African male adolescents affected when their fathers are absent in Zimbabwe?

In general, the period of adolescence is regarded as that between childhood and adulthood. During this period, children undergo physical, emotional, social and spiritual developments. The Book of Proverbs reflects on how parents are significantly valued at this point, as adolescents push for autonomy and search for identity:

My son, keep your father's commands and do not forsake your mother's teaching. Bind them upon your heart forever; fasten them around your neck. When you walk, they will guide you; when you awake, they will speak to you. For these commands are a lamp, this teaching is a light, and the corrections of discipline are the way to life. (Pr 6:20-23)

The above quotation led the authors to ask questions such as: Who is guiding the male adolescents when the fathers are absent? Is it possible for an adolescent to keep the teachings of an absent father? The authors further wondered whether the Church and society are aware of the repercussions of absent fathers in the lives of their male adolescent children. The incidents of absence amongst fathers as a result of migration challenged the primary author, especially, for failing to minister to the male adolescents whose fathers have migrated.

Thus, having realised that many fathers have been forced to migrate from Zimbabwe because of the poor economic and socio-political situation, the authors formulated the following questions to use as the basis for researching this problem and to guide the study in meeting its objectives and aims in this regard:

- Is the absence of fathers due to migrant work traumatic to male adolescents?

- What challenges do African male adolescents face as they grow to manhood without their father's guidance in Zimbabwe?

- What do these children miss about their fathers during the transitional period to manhood?

- How can male adolescents be helped to grow into adulthood in the environment in which their fathers are missing?

\section{Objectives of the study}

The principal objective of this study is to assess the traumatic impact of the absence of fathers on their adolescent male children. Although the causes and socio-economic consequences of migration in the home countries of emigrants may generally be suggested, it is difficult to determine, in great depth, its impact on African male adolescents as they grow into adulthood without sufficient research. The study will therefore:

- Explore and identify the impact of absent fathers on their male adolescent children and whether the absence of fathers can be classified as traumatic for children.

- Explore and identify the pastoral role of the Church in caring and guiding those male adolescents whose fathers are absent.

- Search and develop a methodology that facilitates pastoral care for male adolescents to create awareness amongst migrated parents of the tragedy of their absence for their adolescent male children in particular. 


\section{Aims and benefits of the study}

The aims of this study relate to assisting male adolescents in Zimbabwe to cope with the absence of their fathers in the following ways:

- To help male adolescents draw their strength in their journey to adulthood from other men in the community of faith in the absence of their fathers.

- To empower male adolescents to create a positive image of a father through group discussions in order for them to become worthy men as they grow up to be adults and fathers themselves.

- To bolster male adolescents' own self-worth, in order for them to live positively in the absence of their fathers.

The benefits of this study relate to the Church's role in these male adolescents' lives, in that:

- It gives the Church an opportunity to identify the strengths and weakness of their support systems in caring for male adolescents within their changing environment.

- It enables the Church to identify opportunities for complementing the fathers' and extended family's efforts in supporting those male adolescents whose fathers are absent.

\section{Assumptions and limitations of the study}

The study is guided by the following assumptions:

- Male adolescents are affected by the absence of male parents.

- The church is the most appropriate instrument in helping those male adolescents whose fathers are in the Diaspora. As such, Denton (1952) articulates Freud in the following way:

Only religion is able to answer the question of the purpose of life. One can hardly go wrong in concluding that the idea of a purpose in life stands and falls with the religious system. (p. 26)

The authors also identified the following challenge, which limits the study's findings:

- Only male adolescents from the Methodist Church participated, thereby limiting the generalisation of the findings.

\section{Methodology}

In this study, both qualitative and quantitative research methods were used, because, whilst the authors have some knowledge of the subject, they cannot claim to understand what the children experience until they share with them. Thus, it is through qualitative and quantitative research processes that new insight will be revealed. This will help the adolescents to deal with unique experiences of their situations, or what White and Epston (1990:56) call 'unique outcome', which in narrative therapy refers to '... "facts" or events that contradicts the problem's effects in their lives and relationships'. The reader should note that what 'fact' means in this context of the research is that the research process will help the adolescents to understand their world and themselves better. This understanding will further help them to modify whatever ideas they hold about themselves, their fathers and the world. The experience and knowledge gained through that process thus led the researchers to draw conclusions on the impact of absent fathers on the lives of their adolescent sons.

\section{Co-researchers}

In this study, the adolescents and the church stewards are considered co-researchers. This is because the research is a shared activity in which the authors and adolescents want to understand the world and themselves better. As such, the authors embrace a narrative approach that 'strives for participatory interaction' (Müller, Van Deventer \& Human 2001:78) with the adolescents in order to understand the facts or events in their environment and lives.

\section{The use and benefits of interviews}

The authors chose to use an interview method to collect data in order to gather information of greater depth. As stated by Seale (1998):

The interview is a more flexible form than the questionnaire and, if intelligently used, can generally be used to gather information of greater depth and more sensitive to contextual variations in meaning. (p. 128)

When gathering the data, the primary researcher listened to the co-researchers' verbal and non-verbal messages because verbal language alone was incapable of expressing their inner feelings. In addition, several open-ended questions were used for probing purposes in order to record spontaneous answers and ensure that all questions were understood and answered. The age group of 10-22 years was sampled for the interview in order to identify how each male adolescent feels about his absent father.

\section{Listening beyond tears to hear words}

In his journey with the children, the primary author looked at ways that would lead to a model that protects male adolescents in their passage into adulthood. In this article, these adolescents were important in designing an intervention plan for their own situations. Gerkin (1997) acknowledges this initiative in the following way:

To care deeply for persons is to inquire with them, search with them, question with them about what the events of their lives mean at the deepest level. It also means to inquire with them into the ways in which their questions (and experiences) have been presented in the past and how those questions have been answered, most particularly with the people of the Bible. (p. 125)

This shows that when journeying with the children, the pastoral caregiver should listen to issues which affect them. Listening gives value and meaning to the situations in which the children find themselves. Listening goes beyond hearing what children say about their situations, to involve taking note of their emotions, tears and silence as they communicate their inner life. According to Gerkin (1997:91), 'it means listening for hidden conflicts, unspoken desires, unspeakable fears, and faint hopes ...', which the caregiver should handle pastorally. 
In this case, the primary author had never thought that children who are living with their mothers would ever long for their fathers in such a shocking way. Listening to their experiences challenged his previously held belief that what he had always thought of as being important in the lives of children was material provision and their mothers' love. This was because, in Zimbabwe, the mother is thought to play a key role in nurturing of a child. Thus, during the research stage of this article, the primary author recognised three important perspectives amongst the Africans in Zimbabwe when it comes to guiding children, namely, (1) both parents are central in the life of children, (2) life is viewed in three stages: childhood, adulthood and old age and (3) that the community is important in providing material for identity development a person's life.

\section{Parents are a sacred reality}

Parents are a sacred reality in the life of African children because they are considered second only to God. The absence of fathers represents the absence of God amongst African people in Zimbabwe. This is because the role of a father in Zimbabwe is to guide, provide and protect his sons. Therefore, when God or his representative is absent, people have no direction and are equated to sheep without a shepherd. The absence leads to identity confusion in the adolescence stage, as coined by Erik Erikson (1978) in his human development theory.

It is therefore the father's role to mould a boy child into a man and, for that reason, the boy's life depends upon proper guidance by the parents. The Bible further recognises the role of parents in every God-fearing family in the following way:

Hear, O Israel: The Lord our God, the Lord is one. Love the Lord your God with all your heart and with all your soul and with all your strength. These commandments that I give you today are to be upon your hearts. Impress them on your Children. Talk about them when you sit at home and when you walk along the road, when you lie down and when you get up. Tie them as symbols on your hands and bind them on your foreheads. Write them on the doorframes of your houses and on your gates. (Dt 6:4-9)

This shows that parents are important in guiding children into adulthood.

\section{The three stages of human life in Zimbabwe}

The reader should be informed that the adolescence stage was not understood in the same way as it is today amongst the Africans in Zimbabwe. This is because human life had three major recognised stages, namely childhood, adulthood and old age. Preparations of a boy child into manhood began immediately after a boy was weaned, at or after four years of age. At this age, boys would accompany men or sit where they were gathered for the purpose of being guided by them. During this time, men would discuss issues that helped show boys how to be men and this is just as necessary today as it was in the past when fathers guided their sons. The training of boys and men was not confined to one age group but continued right through a person's life. This is why even old men are referred to as boy by their fathers and elders in Zimbabwe.

The Bible and history have revealed that parenting was considered as an important family and religious role that was carried out wholeheartedly. The home was indeed an institution and a place of parental teaching and child rearing (Zuck 1996:112).

\section{The role of community in the identity development of a male child}

The community and the individual are important in understanding the environment in which African adolescents are raised. This is because, during childhood development, it is the community that provides the materials that are used for identity development. The failure by the male adolescent to draw his strength from the community resources leads to traumatic experiences in the male child's life, because it is a disruption of one's normal growing process and environment. The community builds and influences the individual's personal identity; hence, the African idiom that 'it takes the whole village to raise a child'. When identity undergoes a normative crisis, the probability of irreversible damage cannot be ruled out if the child is not disciplined or guided as he goes through the various developmental stages in his life.

\section{Caring for male adolescents living in risky environments}

\section{A pastoral care model for male adolescents}

The shepherding model coined by Gerkin (1997:23-24) helps the researchers to create a model that shows the roles of God's people to the community. For example, Gerkin (1997) shows us how the priests, wise men and women offered counsel regarding issues of good life and personal conduct. He states that prophets confronted people who deviated from the will of Yahweh. On the other hand, James Fowler (1981) provides the structure through which faith develops and demonstrates how an individual can easily be seen as having a mature faith in God. This study has revealed that the role played by the Church will help adolescents to develop their faith when they are nurtured through love.

Equally, the Zimbabwean society has human resources that have carried out roles in the past, as already alluded in this article. It is from such resources that the authors seek to design a model that draws its strength from biblical, African culture and contemporary practices. Gerkin (1997) subscribes to such a view in his pastoral care approach by dealing with an individual and the community, when he states that:

Pastoral care involves not only the care of the individuals and families, but also the care of the community itself. Pastoral care also entails the thoughtful reinterpretation of the tradition that shapes Christian identity as that tradition is brought into dialogical relationship with contemporary culture and its impact on the community of Christians as well as its individual members. (p. 118) 
Gerkin shows us that pastoral caregivers should be aware of the communities that surround them and which have influenced individuals in their worldviews. This awareness helps them to interpret the social conditions in order to determine what affects people in the community of faith and society. Moreover, relationships in African cultures are very important for they include all people with which one interacts, including those in need. The African practices of caring should connect the reader to the parable of the 'Good Samaritan' (Lk 10:25-35). For example, when someone's house catches fire it takes the whole village, visitors included, to put out that fire. Furthermore, it is within the African way of living to attend a funeral without being invited by the relatives of the bereaved. The above examples simply show the reader how the Church can take advantage of the African practical ways of caring by being viewed as part of the community's extended family, which would see the community incorporate it into their daily lives as part of the extended family system of care giving. It is with this understanding that the primary author engaged in dialogue with the male adolescent interviewees in order to deal with these human realities and deficiencies.

\section{The minister as shepherd of the community}

In the Methodist Church in Zimbabwe, ministers, as shepherds of the flock of God's people, have great influence on the members of the congregation. The ministers' influence extends to the society in which they and their members reside. For example, they attend to situations that affect people in the society through their role of shepherding those under their care. Also, communities solicit the ministers' presence when faced with situations that may require a representative of Christ and this makes it possible for ministers to guide the churches that they lead to care for the adolescents by creating a permitting environment for the expression and receiving of care.

For example, during the research, a child indicated that his father had asked a minister of religion to guide him when he was leaving for the United Kingdom. In spite of being aware of other human resources in society, the father chose to invite the minister to guide his child. This shows that the father is aware that the Church has great influence in helping people to live purposely. The child informed the primary author that he appreciated being guided by the minister. He indicated that the regular visits that the minister had made so far benefited him. He said that the minister prayed with him and sometimes shared many other issues of life. Gerkin (1997:82) helps the reader when he articulates the importance of care in the following way: '... While singing can express care and acknowledgement or mutual need for care. Praying together can search for and celebrate the receiving of the care that only God can provide.' This shows that prayer gives us confidence in approaching God. It is through prayer that we are at home with ourselves because of the care that God gives to those who meet with him in prayer.

A survey carried out on the role of the clergy in caring for those children whose fathers are absent showed that little or no spiritual support is given to the boys in the Methodist Church in Zimbabwe. Children expect the clergy to understand that boys are missing their fathers and that spiritual support is just important. Children in this study indicated that when there were problems between parents, the ministers normally attended to their mothers only. The Gospel according to John illuminates the role that the clergy should carry to the flock, which includes the lambs, when it states the charge that was given to the Apostle Peter:

When they had finished eating, Jesus said to Simon Peter, 'Simon son of John, do you truly love me more than these?' 'Yes, Lord', he said, 'you know that I love you.' Jesus said, 'Feed my lambs ... Take care of my sheep.' The third time he said to him, 'Simon son of John, do you love me?' Peter was hurt because Jesus asked him the third time, 'Do you love me?' He said, 'Lord, you know all things; you know that I love you.' Jesus said, 'Feed my sheep ...' (Jn 21:15-17)

Here, Jesus is first and foremost concerned for the lambs and later the sheep; they were to be fed by the apostle. The above quotation also shows that the apostle is a man who should facilitate the care of the lambs and sheep through his influence in the community. One who feeds the flock cares and is concerned for their safety and health. It simply gives an understanding of how Jesus feels about the flock, which includes children, and it is from this understanding that the minister should care for the young people in their church at individual and group levels in order to identify their joys and frustrations.

\section{Pastoral care for male adolescents in the Church and community}

The Church is an important institution of care for God's people. It is through the Church that believers show God's love and care for one another. Later, this love is expressed through the societies in which children live. Gerkin (1997:95) informs Christian communities of the importance of engaging with people within their situations in order to care for them effectively. It is through their community that children can be helped because when therapy and care overlooks people's environment it becomes irrelevant, particularly in Zimbabwe. The cultural practice of communal life amongst the people of Zimbabwe may be challenged by the modern person, but it remains in the hearts of its people. Therefore, care of the adolescents should take cognisance of the family network. In Zimbabwe, no one would like to die in church, hospital and particularly in the absence of relatives, but rather in a home surrounded by ones' own people and a community of faith. In the event that death approaches whilst in the hospital one will try to wait for or call one's own relatives or children before dying. Gerkin (1997) submits to this thought when he states the role of a minister in the following way:

... It is therefore not enough for pastors to become relatively competent psychologists and therapeutic counsellors if they are to adequately perform their pastoral role. They need also to become competent in helping people make connections between their lives of faith within the community and tradition that identifies us as the people of God, and the day-to-day individual, social, and cultural realities of our lives. (p. 95) 
Therefore, the Church's role is to enter into dialogue with families, especially the families of those children affected. When the Church engages and complements parental roles in nurturing boys, the world becomes a safe place for our sons. Children, when properly guided by the Church and society, can be the light that shines in the lives of their families and society. When the Church carries the role of caring for the children by cementing relationships, practical theology retains the role of creating harmony in its interactions with the environment in which people live.

\section{Pastoral care as the care of individuals}

Whilst boys are individuals with particular challenges in this study, they also form a community of children faced by a situation in which the major variable is an absent father. This absence has bred insecurity, a lack of primary male role models and a lack of masculine love, care and guidance.

During the research journey, children informed the primary author that they would want to meet him first as individuals and then as a group to discuss issues that affect them. Fowler (1981) is an important source in this regard, when he states that although adolescents have external influences they are individuals who are unique in their perspectives. The Church should therefore encourage members of the clergy, youth workers and preachers to see these children as being in need of spiritual support at both the individual and group levels. It is therefore important that the adolescents whose fathers are absent be considered as individuals. The pastor and his leaders should inform their church members of the need to care for individual male adolescents with the available human resources.

\section{Pastoral care for male adolescent groups in the congregation}

Group discussions are important in helping children to deal with various issues of life. Participants receive stimulation from others, with the issues of other group members triggering their own. The frequency of the gatherings also creates trust and confidence and when confidence is created, disclosure is encouraged and confidentiality maintained. Group participation therefore leads to better quality decisions and creates a healthy and conducive environment for the group members. When leadership functions are vested in the group, it is stronger than when it relies on any single member of the group. When children do things together they feel secure. This is because the coming together of people symbolises unity, strength, love, and care and group identity.

This is a stage that Fowler (1981) calls synthetic-conventional faith because, during this stage, there is a reliance on external authority and its construction of meaning in interpersonal images. It is conventional in that it is seen as being a faith system for the entire community and synthetic in that it is non-analytical: it comes as a sort of unified global wholeness. It is a conformist stage which depends upon the expectations and judgements of others and does not form a separate identity and use autonomous judgement to construct and maintain independent perspectives, beliefs and values which are tacitly held. Santrock (2005) summarises this thought when he states that:

According to Fowler, although this stage is abstract than the previous one, young adolescents still mainly conform to the religious beliefs of others and have not yet adequately analyzed alternative religious ideologies. Someone's behaviour that involves a question of right and wrong is seen in terms of the harm it does to a relationship or what others might say. (pp. 295-296)

Youth workers should be present to guide the group leaders and to lead certain topics. This is because young people may have not yet reached a stage where they take responsibility for their religious beliefs and lives. When they are properly guided, they realise that they can choose the course of their lives without much influence from the outside. They can then analyse their course of action. For example, with proper guidance, they will appreciate the efforts of their fathers and the situation in which they find themselves. Guidelines should also be laid down on issues of confidentiality and building of trust in members. Once these are in place, lessons topics that should be discussed in the groups include:

- the role of father

- how to support the father when he is out of the country

- how to relate to mothers when the father is absent

- how to support each other in growing into adulthood

- the role of male family members in the lives of boys when the father is absent

- the importance of the church (helping the church to help us).

The reader should note that in the Methodist Church, as in many others, youth groups that allow boys and girls to meet separately do exist. The youth group for boys is called Boys Christian Union (BCU), in which boys are grouped according to their age. For example, Junior BCU comprises boys between the ages of 6 and 12 years of age, whilst Senior $\mathrm{BCU}$ includes boys from 13 to 22 years.

The youth leaders of these groups should pick topics which cover diverse issues that affect all boys today, without separating them from the existing groups. In that way stigmatisation will be avoided. The youth leaders and advisors should be aware of the developmental challenges of children at this stage, because differences in opinion or non-conformity may make one feel unwanted or a misfit of the group. This is where the role of mature Christian youth advisors is important in guiding and caring for the group that is maturing at different levels.

\section{The pastoral role of Christian men towards male adolescents}

In the past, boys sat where men gathered in the evening to listen to stories and other conversations. These were deliberate gatherings at which men fellowshipped and shared their wisdom and experiences with each other. Boys benefited 
through these gatherings and informal lectures. Because this way of disseminating important information to the children already exists within the Zimbabwean community structure of guiding children, churches can take advantage of the design. Children would benefit from Christian men to learn how men of integrity passed through to adulthood. Christian men should meet with boys at church to share with them how they grew up and how boys would grow up in the absence of their fathers. Men in the Church should approach issues that affected them and what can affect the children today with honesty. They should reveal how other men in the Church and family have helped them to grow in their Christian faith. There is need for the Church to encourage all boys in each congregation to have elders who would mentor them.

The Bible guides us in this way of caring when the Apostle Paul refers to Timothy, in 2 Timothy 2:1-2, as his son in Christ, when he declared that:

You then, my son, be strong in the grace that is in Christ Jesus. And the things you have heard me say in the presence of many witnesses entrust to reliable men who will also be qualified to teach others.

The Bible also records how Eli mentored Samuel (1 Sm 1:21-25). From these biblical examples, boys whose fathers are absent can benefit when men within the Christian community complement the role of the extended family in guiding them. At this point, the authors are also reminded of how Jesus, at adolescence, entered the temple courts. The Bible tells us that his parents found him in the temple courts, sitting amongst the teachers, listening to them and asking them questions (Lk 2:41-46). The above thoughts show how God-fearing men can be of benefit to the male adolescents in each local church.

\section{Pastoral care in training caregivers of adolescents}

Training is an important component of pastoral ministry. Ministers have instructed believers formally and informally on Christian living and what it means to care-for the tradition of faith, for the community of believers, for individuals and families and for the socio-cultural milieu of the believing community (Gerkin 1997:94). Therefore, the training of men's groups on caring for male adolescents on various topics fits very easily in the minister's programme. The minister should take the task of training his or her male groups, youth leaders and advisors in the skills needed to help the male adolescents whose fathers are absent discover their purpose and a male identity that is worth living for. Boys make wise choices when love and care are expressed in practical ways by men with whom they interact at deep spiritual levels. For example, when Christian men reveal weaknesses and strengths in their interactions with them, children will appreciate their efforts in mentoring. Every opportunity these men spend with boys will definitely yield results.

The purpose of these groups is to reduce the trauma experienced by male adolescents as they grow into adults when their fathers are absent. It is this relationship that helps them equip the boys to form a communal and an individual male identity of their own. Thus, the training should take cognisance of how the Zimbabwean Black African societies historically structured the training of a boy child. The training ought to include lessons on how to be men of integrity, how to mentor a boy, the role of the community and parents in the life of the boy child. The parents of these boys should also be made aware of the Church's programme in guiding boys. The training aims to equip men to be Christian mentors. Therefore, Christian mentors should note that children are also being guided by other male adults in the community and in their family, particularly in emotionally close families.

Whilst training has been emphasised for men's groups and youth leaders, there is also a need to create awareness amongst the whole congregation of the need to care for adolescents. When the whole congregation has an appreciation of the programme, its influence may bring other boys to church.

\section{Fathers working with the whole family in honesty}

The African family system in Zimbabwe has existing structures that can be taken advantage of for the purpose of caring for the children whose fathers are absent. What is important for the fathers to consider before leaving the country are the men who would mentor their sons. The departure of fathers carries great weight when they leave their sons with men of integrity to guide them.

In the past, it was not difficult to find male adults who would take up the role of mentoring children. A father did not need to scratch his head about who to leave his children with; instead, absent fathers were anxious about how they would achieve their dreams. Fathers should discuss their expectations and commitment to parenting with members of their extended family to ensure that they do not leave their children in risky situations. This will help them appreciate the importance of guiding these boys in the ways the father wishes. If they do not, as suggested by the children in this study, it would be better for them to suffer together with their fathers here in Zimbabwe.

The father should also inform his sons about the purpose of going to work out of the country, as well as the importance of a disciplined life and the roles that other male members in the family will play in their lives. When fathers discuss openly with children the foreseeable benefits, challenges and what should be done in response, they will have prepared them for their absence. In John's Gospel, Jesus notifies the disciples of the conditions on which he was going to send them the power of the Holy Spirit when he said:

If you love me, you will obey what I command. And I will ask
the Father, and he will give you another Counsellor to be with
you forever - the spirit of truth ... I will not leave you as orphans
I will come to you. (Jn 14:15)

This shows that it is important to find mentors when fathers are absent. Boys should be helped to understand that they 
benefit when they listen to the advice of the adults both in their family and Christian community in the absence of their fathers.

\section{Fathers and mentors should know the friends of male adolescents}

This model does not just emphasise therapy, but offers a way of caring for the adolescents whose fathers have left the country, as well as those whose father wish to leave in the near future. As such, here are some guidelines for fathers about the subjects they should discuss with their children before and after they leave them in the care of others:

- Teach them to walk with wise men.

- Discuss with them the biblical perspective of characteristics of a wise man. Examples can be drawn from Psalms 1:1: 'Blessed is the man who does not walk in the counsel of the wicked, nor stand in the path of sinners, nor sit in the seat of scoffers.'

\section{Examples of quality friends for adolescents}

Male adolescents should have quality male friends who will help and encourage them in their journey to manhood. Quality friends are friends of Jesus Christ, as referred to in the Gospel of John 15:14: 'You are my friends if you do what I command.' Moreover, the Bible provides many examples of good friends, as summarised below:

- 'A good friend is not driven by instant gratification. But a bad friend says, eat, drink, and merry, for tomorrow we will die' (Pr 23:6, 20-35).

- 'A good friend is loyal, but a bad friend is fickle' (Pr 24:21; 25:19)

- 'A good friend speaks truthfully, but a bad friend "devises violence", and his "lips talk of trouble"' (Pr 24:1).

- 'A good friend loves the law of God, but a bad friend is a lawbreaker' (Ps 1:1-2)

- 'Do not be misled: "Bad Company corrupts good character". Come back to your senses as you ought, and stop sinning; for there are some who are ignorant of God - I say to your shame' (1 Cor 15:13-34)

- 'Two are better than one, because they have a good return for their work: If one falls down, his friend can help him up. But pity the man who falls and has no one to help him up!' (Ec 4:9-12)

Children are living in a world with many ways to connect socially and thus spend more time with friends at school and out of school. Therefore, it is the job of the father to know his son's friends, as well as where and how they spend their time. To put it another way: it is the role of the father to know the primary influences on his son. This is why the authors believe that a father should consider his son's environment from morning to evening. Material support alone without a plan for building an internal structure of support for male adolescents particularly, destroys them, as already alluded to above. Fathers should equip their sons to live in a world of many voices, in that they are in the world, but not of the world. They have to be equipped to interact with nonbelievers, to be exposed to media, politics and peer pressures, but to still maintain their boundaries and fear for God. As a result, the father's role will help them to follow the familiar voice of Jesus, their friend and chief shepherd.

\section{The benefit of the research to the adolescents}

The primary researcher met with the adolescents three months after the initial research interviews. This was upon the request of the boys that they wanted to discuss with him on a different level, other than that of a research project. Secondly, they requested this meeting because they could not suggest a way that would enable them to create a male identity for themselves because of the emotions involved in the first session. It seems the children were very emotional about the discussions on that initial occasion because it was the first time that they had been afforded such an opportunity to talk about their experiences of their absent fathers.

One of the outcomes of the second meeting was that it afforded the primary researcher the opportunity to understand how his research has benefited the male adolescents involved, allowing them to live positively by:

- Accepting that their fathers are human beings who can also make mistakes and should be forgiven.

- Acknowledging that they cannot change their situation and therefore they should appreciate that they have fathers who are supporting them from the Diaspora.

- Recognising that they should please their fathers by working hard at school.

- Admitting that they should have good friends to guide them in life.

- Realising that they should have a positive attitude about their lives.

- Accepting that their fathers will not find it easy to come back home, because the Zimbabwean situation does not promise early economic recovery that may create jobs for them.

The session helped them to be part of a community that is facing similar situations and gave them an opportunity to share their views about the absence of their fathers. Lastly, the children felt that they can benefit from their guardians, family members and their teachers to be good children in the society when their fathers are absent.

\section{Guidance as a pastoral responsibility for adolescents}

Despite the mistakes and other shortcomings encountered by children when their fathers are in the Diaspora, the primary researcher guided the children in the following way:

- The boys should strive to forgive their fathers in order to destroy the seed of bitterness that may lead to various pathologies in their lives; because Christ set forgiveness as a condition of being forgiven.

- They should not condemn or judge their fathers over these past shortcomings which may only be understood in their real context when discussed with elders in the 
family. For example, some practices that people follow are cultural expectations which fathers were fulfilling. These expectations may only be understood and dealt with by an individual and the society through dialogue and biblical examples of love.

- They should discuss the issue with some elders in the Church and society to understand the African man's view of being a father. Adolescents were also asked to hear from the family members how their fathers grew up, including the relationship with their own fathers and the role they played in guiding their sons.

- In the event that their fathers do not communicate, a boy should discuss his pain with his father's brothers and sisters (aunts), as well as other Christian men in the community. In Zimbabwe, one's father's brothers are regarded as being their fathers too, because the brothers share the same parents and nurturing environments. The reader should note that aunts are also a source of strength for their nephews.

\section{Research worth undertaking}

Researching the traumatic effects on male adolescents in Zimbabwe whose fathers are absent as a result of migrant work benefited the primary researcher in that it allowed him:

- To understand that a father's absence affects children emotionally.

- To recognise the impact of absence on his own children and discover a model to care for them as well.

- To realise that boys need someone to share in their joys and sorrows in the absence of their fathers.

- To appreciate that whilst people's situations vary, they all need someone to talk to in order for them to create and find solutions to their predicaments.

- To understand that some relationships can be managed - but perhaps not completely healed - when people find guidance. For example, some children accepted that they still love their fathers despite the betrayal they experienced. This shows that, with time, even those who have not yet come to terms with their situations may still positively manage them.

It is important to continue meeting with young people and listening to what they are going through. Listening to people in need either as a group or as individuals is another way of caring. To this end, the aims and objects of the research were realised, in that the impact of absence was identified, the community was made aware of the situation and their role in it, and a shepherding model was created to help the boys in need, to the extent that they became empowered in their lives. Recommendations for further research and assistance in this area are discussed below.

\section{Insights from the research journey}

African adolescent children are affected by the absence of their fathers just as much as their Western counterparts. Consequently, the absence of fathers seriously impacts the children when father-mother relationships are strained to begin with, to the extent that one child felt that having a dead father was better than having an absent one. This was because the boy felt his father had not influenced him in any way. The boy felt that he had learnt nothing from his father apart from receiving messages that he will one day go back with him to the Diaspora when he visits home. Despite the material support he was receiving, the boy felt cheated and betrayed. Children expect fathers to protect them and so to be hurt or emotionally harmed by them is a betrayal of trust. This hurt would be carried through life and lead to further traumatic experiences.

The authors also learnt that some children who are well supported materially did not see the importance of a having their father present. They felt comfortable growing up under the guidance of their mothers. This was because of the value they placed on feminine warmth and tenderness, whilst they did not seem to admire much or miss the masculine strength and warmth their father would have provided. This shows that some children have developed unfinished issues with fathers that need to be dealt with in spite of the material support received. Dealing with these issues is an important step in a male adolescent's life, otherwise he will have difficulty in discovering the man within himself. However, most children do want to grow up in the presence of their fathers so that they can learn from them and create a male identity from their interactions.

Generally the boys feel they cannot change their painful situation by lamenting over the absence of their fathers but that they need to focus on their studies and do well. However, the authors thought that this idea, without any further guidance, may lead to the boys becoming emotionally insensitive men who are introverts or only focused on the task at hand. This behaviour may also lead the children to be unfriendly to women in order to have freedom from both same and opposite sex relationships.

\section{Conclusion}

The migration of fathers to the Diaspora could not be resisted by men because of the socio-economic situation in Zimbabwe; fathers have left the country for greener pastures. The exodus of fathers to the Diaspora has created a vacuum in mentoring and moulding male children into adult men. The study carried out with adolescent boys indicated that fathers in the Diaspora are engaged in some form of employment. As a result, fathers are able to provide for their families back home. This group felt that the absence of fathers benefited them.

However, the absence of these fathers has made some children feel emotionally abandoned and betrayed, whilst others were disappointed by fathers who did not bid them farewell and are irresponsible. The feelings of these children make them fear involvement, limit father-son relationships, generate anger, bitterness and lack of any future dependence on their fathers. When children are angered and bitterness resides in them, they would go against their father's potential assistance. 
On the other hand, in the process studying the impact of absent fathers, a Christian model of caring of the individual and community emerged. The Church has been noted to be the only institution that would be able to guide the society to value the job of caring for the people of God who are in need. When the Church cares for the adolescents they will be caring for the body of Christ. As such, the authors drew on Gerkin (1997) and Fowler (1981) to explain the view of the Church as a community of faith to signify a fellowship of love or community of love. For it is only by Christ's love that we are forgiven by God through grace. It is through love that people are nurtured and miracles of spiritual and numerical growth are seen.

Acts 2 bears witness to the power in love fellowships. In sharing the gospel of Christ in love fellowship, each member becomes a part of Christ's body that spreads the gospel. The love fellowship allows the Church to do more than just preach or provide meeting points. It becomes a family where all members have the opportunity to share their experiences at fellowship and individual levels. People will not depend on one person for spiritual growth but on each other for spiritual nourishment. Therefore, caring for those boys whose fathers are absent requires both individual mentors and local communities to mentor them. The people will know through these fellowships, that the Church represents Christ (Jn 13:35). In his letter to the Corinthians, Paul equates a fellowship of love with a human body. He states that there is no division in the body, but concern and sensitivity to the needs of one another. If one part of the body suffers, all the other parts suffer with it (1 Cor 12:25). The Methodist Church has been found wanting by the boys in this study, who indicated that the Church was not aware of their pain. This shows that the Church was unable to see the depressed and hear the silent voices in order to interpret the situation and reveals that the Church has some parts that are in need of spiritual attention in order for the body of Christ to function optimally.

The above model will help children who feel negatively about themselves as a result of their absent fathers. Children will open their hearts in love fellowships in order to be healed, nurtured, sustained and guided through love. Faith will be expressed in a more mature and responsible way when all is done in love. In this study, faith is the act of love that guides individuals and communities to an expression of freedom and responsibility in trusting God's presence in human situations. It aims to increase love for one another and for God. For it is only through Christ's love that healthy memories are created.

\section{Recommendations}

The Church should take the lead in guiding the adolescents before fathers leave the country and whilst they are out of the country. Male groups in the Church should take up the task of complementing the role of the extended family in preparing the adolescents for adulthood. The Church should therefore carry these responsibilities as part of the extended family, which is unique but connected to the family without competing with it.

Furthermore, chaplains in schools, youth leaders and advisors in the Methodist Churches should pioneer the programmes that help adolescents prepare for adult life through, (1) group discussions, (2) drama productions, (3) organised outings, (4) sharing testimonies from those adults who have passed the stage of adolescence in the absence of their own fathers and (5) debates focused on the concepts of fathers and fatherhood.

Finally, fathers should discuss with children, in all honesty, the purpose of their departure before they leave the country. They should also not raise their sons' hopes by promising too much. This will help children to continue trusting them.

\section{Acknowledgements Competing interests}

The authors declare that they have no financial or personal relationship(s) which may have inappropriately influenced them in writing this article.

\section{Authors' contributions}

This article has been adapted from the PhD dissertation of A.K.N. (University of Pretoria) which was completed under the supervision of M.J.M. (University of Pretoria).

\section{References}

Denton, W., 1952, What's happening to our families?, The Westminster Press, Philadelphia.

Erikson, E.H., 1978, Identity and the life cycle, W.W.Norton \& Company, New York.

Fowler, W.J., 1981, Stages of faith: The psychology of human development and the quest for meaning, Harper \& Row, San Francisco.

Gerkin, C.V., 1997, An Introduction to pastoral care, Abingdon Press, Nashville.

Müller, J., Van Deventer, W. \& Human, L., 2001, 'Fiction writing as metaphor for research: A narrative approach', Praktiese Teologie in Suid-Afrika 16(2)1, 79-96.

Santrock, W.J., 2005, Adolescence, 10th edn., Mc Graw Hill, Boston.

Seale, C., 1998, Quality Qualitative research, Sage, London.

White, M., \& Epston, D., 1990, Narrative means to therapeutic ends, Norton, New York.

Zuck, R., 1996, Precious in His Sight; Childhood and Children in the Bible, Baker Books, Grand Rapids. 